\title{
Tersine Dönen Emek Arz Eğrisi: Türkiye Sınaması
}

\section{Backward Bending Supply of Labor: Case of Turkey}

\author{
Mehmet ŞENGÜR, Eskişehir Osmangazi Üniversitesi, Türkiye, msengur@ogu.edu.tr \\ Orcid No: 0000-0002-2173-9977
}

\begin{abstract}
Öz: Mal ve hizmetlerin üretimi için gerekli olan temel üretim faktörlerinin başında emek gelmektedir. Emek arz miktarl genellikle hanehalkına ya da bireylere bağlıdır. Temel olarak ücretlerdeki bir artışa bağlı olarak emek arz artışı da beklenen bir sonuçtur. Genel kabul gören bu varsayımın her zaman geçerli olup olmadığı da tartışılan diğer bir olgudur. Bireylerin ya da emek arzı sahiplerinin bir takım faktörlerin etkisi ile boş zamanı çalışmaya tercih ettikleri bilinmektedir. Diğer yandan bazen bireyler ücret artışına ragmen çalışmamayı da tercih edebilirler. Artan gelire rağmen oluşan bu durum tersine dönen emek arz eğrisi kavramı ile açıklanmaktadır. Emek arzında bulunan bireyler kendisine zaman ayırmak, aile ile daha çok ilgilenmek ya da iş dişında diğer şeylere yönelmek gibi sebeplerden dolayı boş zamanı tercih etmektedirler.

Bu çalışmada ücret artışına bağlı olarak emek arzındaki değişim Türkiye için incelenmektedir. Hanehalkı araştırma anketi verileri kullanılarak yapılan analiz sonuçlarına göre; Türkiye'deki emek arzı sahiplerinin başlangıçta genel varsayıma uygun olarak ücret artışı ile birlikte emek arzında artışı tercih ettikleri görülmüştür. Bireylerin zaman içinde artan ücretler karşısında belirli bir noktadan sonra farklı davrandıkları tespit edilmiştir. Türkiye'de emek sahipleri artan ücretler karşısında belirli bir gelir seviyesinden sonra boş zamanı tercih etmektedirler. Bu çalışmada elde edilen analiz sonuçları Türkiye'de emek arz ĕgrisinin geriye bükümlü ya da tersine dönen bir seyir izlediğini ortaya koymaktadır.
\end{abstract}

Anahtar Sözcükler: Tersine Dönen Emek Arzl, Ücret, Gelir, İkame Etkisi, Gelir Etkisi

JEL Sinıflandırmasi: E00, E20, E24

Abstract: Labor is the most important production factor for the production of goods and services. The amount of labor supply usually depends on the household or individuals. Basically labor supply growth is expected to increase in parallel with an increase in wages. However, it is disputable whether or not this generally accepted assumption is always valid. It is known that individuals or labor supply holders prefer, for a variety of reasons, leisure time over work. On the other hand, sometimes individuals may also choose not to work despite the wage increases. This situation, observed despite the increasing income, is explained by the backward supply curve. Individuals who make labor supply prefer leisure time for reasons such as spending time for themselves, taking care more of the family or pursue other preoccupations besides working.

This study examines changes in labor supply in relation with wage increases in Turkey. According to the results of the analysis, which uses the household survey data, it has been seen that laborers in Turkey initially choose to increase the supply of labor with wage increases in accordance with the general assumption. It has been determined that individuals behave differently after a certain point over time in the face of increasing wages. Labor supply holders in Turkey prefer leisure against increasing wages after a certain income level. The results of the analysis show that the labor supply curve has followed a course of twisted backward or backward bending in Turkey.

Keywords: Backward Bending Supply of Labor, Wage, Income., Substitution Effect, Income Effect JEL Classification: E00, E20, E24

\section{Giriş}

Ekonomik faaliyetlerin temel amacı gelirin herhangi bir türünü elde etmektedir. Meydana getirilen toplam gelir ise mal ve hizmet üretim sürecine katılan faktör sahipleri arasında dağılmaktadır. Öncelikle herhangi bir ekonomik birimin üretilen mal veya hizmete hangi aşamada hangi üretim aracı ile katkı sağladığı sorularını cevaplamamız gerekir. Bu sorular cevaplandığı zaman ekonomik birimin gelirden ne ölçüde pay alacağını da tespit etmiş oluruz. Bireyler hangi üretim faktörüne sahip ise gelirden o ölçüde pay alacaklardır. Üretim sonucu oluşan gelirden; işçi ücret, sermayedar faiz, girişimci kar ve doğal kaynak sahibi ise rant olarak payını alacaktır.

Emeğini arz eden bireyler çalışmak ya da boş zaman geçirmek gibi iki farklı tercihle karşı karşıyadırlar. Emek sahibinin önceliği eğer hayatta kalmak ve sosyal yaşamda bir takım faaliyetlere katılmak amacında ise bireyin tercihi çalışma yönünde olacaktır. Normal koşullarda her birey yüksek ücret getirisi olan daha az çaba isteyen bir işte istihdam edilmek isteyecektir. Ancak bu durumun herkes için geçerli olması genellikle mümkün olmamaktadır. İşçilerin elde edeceği ücretin doğrudan çalıştığı süre ile ilişkili olduğu da diğer bir gerçektir. Basit bir mantıkla daha çok saat çalışan daha fazla ücret geliri elde edecektir. Çoğu zaman ilk aşamada bireyler, temel beslenme ve barınma gibi ihtiyaçlarını karşılayacak kadar gerekli olan minimum ücret elde etmek için çaba gösterirler. İlk aşamadaki çaba sonucunda açlıktan ölmek veya barınacak yerin olmaması gibi sorunların çözümü sonucu hayatta kalma ile ilgili engeller de aşılmış olacaktır. $\mathrm{Bu}$ ilk aşamadan sonra ise bireyler toplumdaki ortalama refah seviyesinde ya da ona yakın bir yaşam sürmek isteyeceklerdir. Ortalama refah seviyesine ulaşmak için daha çok çalışıp daha fazla gelir elde etmek isteyeceklerdir. Dolayısıyla refah seviyesi artışı gelir artışı ile doğru orantılı olacaktır. Her ne kadar gelirin diğer türlerini elde bireyler için de geçerli olsa bile, özellikle ücret geliri sahipleri yani emek arzında bulunanlar için yüksek gelirin temel belirleyicisi artan çalışma süresi olacaktır. Gelirde meydana gelecek muhtemel artış beklentisi ile emek arzı da sürekli olarak artış gösterecektir. Ancak bireylerin belirli bir gelir ve refah düzeyine ulaştıktan sonra daha çok çalışmak yerine artan boş zaman tercihlerinin olduğu görülebilir. Boş zamana yönelik artan talep sonuucu emek arzındaki seyir artış değil azalan olacaktır.

Makale Gecmiși / Article History

Başvuru Tarihi / Date of Application Kabul Tarihi / Acceptance Date
: $23 \mathrm{Kasim} /$ November 2019

: 20 Ocak / Jauary 2020 
Bu çalışmada bireylerin daha çok ücret geliri elde etmek için çalışma saatini artıracağı temel varsayımından hareketle tersine dönen emek arz eğrisinin geçerliliği Türkiye için sorgulanmıştır. Öncelikle tersine dönen emek arz eğirişi ile ilgili literatür incelenmiş ve teorik çerçevesi açıklanmıştır. Daha sonra Türkiye İstatistik Kurumu'ndan (TÜİK) elde edilen anket verileri kullanılarak artan gelir ile boş zaman tercihi ilişkisi Türkiye için analiz edilmiştir. Son olarak kurulan lojistik modelin analizi sonucunda elde edilen bulgular yorumlanarak değerlendirmelerde bulunulmuştur.

\section{Literatür}

Tersine dönen ya da geriye dönen emek arz eğrisi ile ilgili literatürde fazla çalışma bulunmamaktadır. Bu çalışmanın özgün tarafı bu konunun çok az çalışılmış olması ve Türkiye için daha önce hiç incelenmemiş olmasıdır. Literatürde yer alan çalışmalar ve ampirik bulguları kronolojik olarak sıralanmıştır.

Fetter ve Miracle (1970), Afrikan'ın ekonomik gelişim davranışının sömürge dönemi boyunca ortodoks olmayan bir yaklaşımdan ortodoks yaklaşıma doğru yöneldiği yaygın olarak kabul edildiğini belirtmişlerdir. Tersine dönen emek arz eğrisinin ortadan kalkması durumunda Afrikalıların ekonomik teşviklere verdiği yanıtın niteliğinde ve gücünde bir sanılanın aksine bir değişiklik olmamaktadır. Bu durum bireylerin değişen ekonomik koşullara verdiği tepkinin değişmesi yerine sadece değişen koşulları yansıtabilir. Orta Afrika'daki işçiler ve emek arzının şekliyle ilgili son zamanlarda yapılan çalışmalar yaygın olarak kabul edilenlere karşı şüpheci alternatifler sunmuştur. Ayrıca Afrikalıların karşılattıkları ekonomik koşullar hızlı ekonomik büyüme için gerekli şartlar altında tahmin edilenden daha fazla fayda sağladığı vurgulanmaktadir.

Ellis (1981), tersine dönen emek arz eğrisini Afrika için ele almıştır. Afrika için yapılan tartışmaların kafa karışıklığına neden olduğunu ve bu karmaşanın sadece emek arzı için değil iktisat teorisinde olan ya da olmayan bir takım durumların en iyi şekilde yorumlanması için de geçerli olduğunu ifade etmektedir. Afrika'daki işçiler için emek arzının tersine dönmesi artan maliyetlerden değil işçilerin boş zaman ve gelir arasında bir tercih yapmalarının sonucudur. Çalışmada Afrikalı işçilerin rasyonel insan olduğu ile ilgili yorum yaparken bu işçilerin maruz kaldıkları kötü ve insanlık dışı muamelelerin de göz önünde bulundurulması gerektiği belirtilmiştir.

Nakamura ve Nakamura (1981), Amerika'da ve Kanada'da yaşayan yedi farklı yaş grubunda yer alan evli kadınların emek arz eğrisinin ücret oranlarına duyarlılığını test etmişlerdir. Çalışma saatlerinin vergi oranlarına ya da vergi oranlarının çalışma saatlerine bağımlılığını aşmak için tekrarlamalı tahmin yöntemi seçilmiştir. Amerikalı ve Kanadalı kadınların emek arzı davranışları üç aşamada incelenmiş ve geleneksel varsayımın aksine ücret teklifi karşısında emek arz eğrisini tersine döndüğü tespit edilmiştir.

Robinson ve Tomes (1985), Kanadalı evli kadınların emek arzı ile ücretler arasındaki esneklik ilişkisi incelenmiştir. Araştırma daha önce Nakamura ve Nakamura (1981) tarafından yapılan analizin güncel verilerle yeniden test edilmesi şeklindedir. Geleneksel olarak kadınların emek arzının ücret esnekliğinin erkeklere göre daha fazla ve pozitif olduğu kabul edilmektedir. Analiz sonuçları Nakamura ve Nakamura (1981)'nın bulgularını güçlü bir şekilde desteklemektedir. Çalışan kadınların gelir artışı ile daha fazla boş zaman tercih etmişlerdir.Bu tercihin sonucunda oluşan gelir etkisinin çalışmaya yönelik ikame etkisinden daha büyük olduğu saptanmıştır. Analiz sonucunda kadınların emek arz eğrisini tersine dönen bir seyir izlediği ve burada oluşan gelir etkisinin erkeklerden daha fazla olduğu tespit edilmiştir.

Just ve Zilberman (1992), çiftçilerin arz miktarı üzerinde etkili olan değişkenleri ve arzın tersine dönen bir seyir izleyip izlemediğini incelemişlerdir. Burada bireysel arzdan daha ziyade çiftçilik ile uğraşan ailelerin emek arzı söz konusudur. Sanılanın aksine çiftçilerin arzının daima pozitif olmayacağı bunun marjinal gelirdeki bir azalma, borç krizi ve servetteki kritik bir azalış gibi sebeplerden dolayı negatif de olabileceği ifade edilmiştir. Ancak bu negatif ilişkinin ampirik olarak ortaya konulması pek mümkün olmayabilir. Ampirik bir ilişki ortaya konulmasa bile arz esnekliği ile ilgili bir takım çıkarımların yapılması da mümkündür. Arz esnekliği servet, fiyatlar ve nakit artışı ile artış eğilimi gösterirken yüksek faiz oranları karşısında düşme eğilimdedir. Ayrıca arz esnekliğinin arazi fiyatları ayarlaması ve risk tercih yapısı ile de yakından ilgili olduğu tespit edilmiştir.

Plott (2000), tersine dönen emek arz eğrileri ile birlikte piyasaların istikrar özellikleri araştırılmıştır. Parametreler seçilirken fiyat dinamiklerini farklı tahminlerle yansıtan Walrasyan ve Marshallyan modeller tercih edilmiştir. Sonuçlara bakıldığı zaman piyasalarda istikrarsızlıklar gözlenmektedir. Ancak tersine dönen emek arzının geçerliliği Walrasyan model tarafından doğrulanırken Marshallyan modelin dinamiklerince reddedilmiştir.

Licona (2000), Meksika'daki hanehalkı yoksulluğunun emek arzı üzerindeki etkisi incelemiştir. Bu çalışma sadece Meksika'daki emek arzının anlaşılması dışında gelişmiş bir ülkedeki refah devletinin gücü hakkında da bilgiler vermektedir. Çalışmada gelir eksikliğinin ve işsizlik programlarının emek arzı üzerinde önemli sonuçlara yol açabileceği ortaya konulmuştur. Aile üyeleri genellikle daha yüksek ücret için emek miktarını artırdığı için eğitim ve çocuk bakımı gibi diğer faaliyetlere zamanları kalmamaktadır. Düşük işsizlik geliri bir iş için talep edilen asgari ücreti de azaltacağı için toplumdaki tüm gelir dağılımı da bozmaktadır. Yoksul aileler için sosyal yardımların zayıflaması ya da azalması da benzer bir sonucu ortaya çıkaracaktır. Çalışmadan elde edilen diğer bir sonuç ise; düşük gelirli ailelerin özellikle kadınların reel ücretlerin düşmesi halinde emek arzını artırarak işgücü piyasalarında daha fazla yer aldığıdır. Elde edilen ampirik sonuçlar tersine dönen emek arz eğrisinin teorik varsayımları ile uyumludur.

Dessing (2002), yaygın olarak kabul edilen emek arz modeli geçim gereksinimlerini ve aile içindeki cinsiyete dayalı katı iş bölümünü de dikkate alarak genişletilmiştir. Filipinler'in kırsal kesimleri için yapılan çalışmanın sonuçları sanayileşmiş ülkeler de dâhil yapılan diğer çalışmaların bulgularını desteklemektedir. Yoğun zaman tahsis anketlerinden 
elde edilen sonuçlar diğer çalışmalar ile örtüşmektedir. Sanayileşme ve kentleşme sürecinde kırsal alandaki ailelerin emek arzı artan ücretler karşısında önce artış göstermekte ve daha sonra ise azalma eğilimine geçmektedir.

Palley (2003), Amerika için yaptığ 1 çalışmada fiyat değişimleri karşısında Ginseng bitki türünün arzında meydana gelen bükülme incelenmiştir. Zaman içerisinde Ginseng bitkisinin arzının fiyat karşısında geriye bükümlü bir seyir izlediği görülmüştür. Bu çalışmanın diğer literatür araştırmalarından farkı biyoloji ve ekonomiyi birleştirmiş olmasıdır.

Lin (2003), gelir etkisinin ikame etkisine baskın geldiği varsayımına dayanmadan tersine dönen emek arz eğrisini açıklamaya çalışmıştır. Klasik işgücü teorisinde çalışma saatleri ve çalışma için harcanan çabalar eş anlamlı olarak ele alınmıştır. Lin ise bu alışılan yaklaşımın aksine, Rasmussen'e (1998) dayanarak oluşturduğu verimlilik ücret modelinde çalışma süresi ile harcanan çabayı farklı değişkenler olarak ele almıştır. Ücretlerde meydana gelen bir artışın işçi üzerinde aynı anda ve doğrudan, çalışma süresi artışı ve harcanan çaba artışı olmak üzere iki farklı ikame etkisi olduğu ortaya konulmuştur. Çalışma daha fazla bir çabanın çalışma saatlerini azaltan bir etkisi olabileceğini ve böylece gelir etkisi olmadan da emek arz eğrisinin geriye bükümlü olabileceğini ortaya koymaktadır. Ayrıca tersine dönen emek arz eğrisinin ampirik olan anlamlı ve teorik olarak ilginç olmasının yanı sıra politika yapıcılar için de önemli olduğu vurgulanmıştır.

Dimov vd., (2004), Malavi'de kırsal alanda yaşayan "ganyu” ismi verilen çiftliklerde çalışan insanlar üzerinde bir araştırma yapmışlardır. Araştırmada 2004 yılı hanehalkı anketleri kullanılmıştır. Neoklasik teori ile uyumlu sonuçlar elde edilen çalışmada tersine dönen emek arz eğrisinin alternatif hipotezi de reddedilmiştir. Ayrıca toplumda bir bütün olarak genel eğitim seviyesinin artırılması, ürün yetiştirmenin ve çeşitlendirmesinin teşvik edilmesinin geleneksel "ganyu” işçiliğine alternatifler oluşmasına katkı yaptı̆̆

Tellez vd., (2009), Kaliforniya'daki kadın hemşirelerin aldığı ücretin çalıştıkları saatler üzerindeki etkisi araştırılmıştır. Kayıtlı hemşireler kurulu anketinden elde edilen veriler iki aşamalı en küçük kareler yöntemi ile analiz edilmiştir. Ücret artışının belirli bir noktaya kadar çalışma saati üzerinde pozitif bir etkiye sahip olduğu ancak belirli bir düzeyden sonra bu etkinin negatif olduğu tespit edilmiştir. Ücretler ile çalışılan saatler arasında doğrusal olmayan bir ilişkinin varlığı saptanmış ve tersine dönen emek arz eğrisinin geçerli olduğu görülmüştür.

Rahman (2013), farklı ücretli işlerde çalışan Kanadalı kadınların emek arz davranışını incelemiştir. Çalışma bilinen işgücü arz modelini Kanadalı kadınlar için test etme amacı taşımaktadır. 2009 yılına ait yatay kesit verileri kullanılarak analiz yapılmıştır. Kadınların emek arzının ücret düzeyindeki değişiklikler karşısındaki duyarlılığını gözlenmiştir. Analiz sonuçları Kanadalı kadınlar için emek arz eğrisinin geriye bükümlü olduğunu ortaya koymuştur.

Pham ve Flaaten (2013), Vietnam'ın Khanh Hoa eyaletindeki kıyı kesimi balıkçılığı için tersine dönen arz eğrisini incelemişlerdir. Palley (2003) gibi ekonomi ile biyoloji birlikte ele alınmıştır. Zaman serisi verilerinin kullanıldı̆̆ı çalışmada tersine dönen arz eğrisinin kıyı şeridi balıkçılığı için de geçerli olduğu görülmüştür.

Stucky, analizlerin çoğu çalışma etiğini sadece meslek bağlamında ele aldığına vurgu yapılmıştır. Oysa ki çalışma etiği farklı sosyoekonomik faktörlerin ve meslek ya da iş etiğinin bir fonksiyonudur. Farklı sosyoekonomik faktörler ile tersine dönen emek arz eğrisinin ilişkisinin sorgulanması gerekir. Bu durum boş zaman karşısında emek arz edildiğinde, elde edilecek gelirle satın alınabilir mal ve hizmet miktarlarının karşılaştırılması ile ilgilidir. Gelişmiş ve az gelişmiş ülkeler için kıyaslandığında emek arzında farklılıklar ortaya çıkmaktadır. Az gelişmiş ülkelerde hanedeki tüm gelir toplandığ için erkekler daha fazla boş zamanı tercih ederken gelişmiş ülkelerde ise durum farklıdır. Bu nedenle kadınların emek hareketliliği de gelişmiş ve gelişmekte olan ülkeler açısından farklılıklar göstermektedir. Gelişmiş ülkelerdeki erkek işgücü kadınların emek hareketliliğinin önünde bir engel oluşturmaktadır ( www.citeseerx.ist.psu.edu).

\section{Kuramsal Çerçeve}

Emek basit olarak mal ve hizmetlerin üretimi için harcanan çabalar bütünüdür. Üretime emeği ile katılan kimselerin davranışları emek arzını da belirleyecektir. Ücret ise emeğin üretimden aldığı pay olarak açıklanabilir. Bildiğimiz şekliyle eğer ücretler artarsa emek arzı yani çalışmak isteyen kimselerin de sayısı ya da çalışılmak istenen süre artacaktır. Dünya genelinde birçok faktörün etkisi ile işgücü piyasaları hareketlenmiş, emek arzında genişlemeler görülmüştür.

Emek arz eğrisindeki meydana gelen bu değişimin arkasında yatan bir takım sebepler vardır. Bu sebepler tercihlerdeki değişim, alternatif firsatlardaki değişim ve göç olarak sıralanabilir. 1950'li yıllarda kadınların sadece \%34'ü ücret karşılı̆̆ 1 bir işte çalışırken 2009 yılında bu oran \%59'a yükselmiştir. Herhangi bir piyasadaki emek arzı diğer piyasalardaki ulaşılabilir fırsatlara bağlı olarak da değişebilir. Eğer armut toplayıcılarının ücretinde aniden bir artış yaşanırsa elma toplayıcıları da bu piyasaya geçmek isteyeceklerdir. Dolayısıyla elma toplayıcılarının bulunduğu piyasada emek arzı da azalacaktır. Emek arzındaki değişimin önemli bir sebebi de işçilerin bir bölgeden başka bir bölgeye ya da ülkeler arası hareketliliğidir (Mankiw, 2012: 382). Bunların dışında emek arz eğrisi üzerinde etkili olan diğer bir faktör de nüfustaki değişimlerdir. Toplumda yaşayan bireylerin sayısı arttı̆̆ı zaman emek arz eğrisi sağa kayacaktır. Buna karşın ülkedeki nüfus azaldığı zaman ise emek arz eğrisi de sola kayacaktır (Krugman ve Wells, 2010).

Emek arz eğrisi, farklı ücret oranları karşısında çalışmaya hazır emek miktarının değişimini göstermektedir. Emek arz eğrisinin şekli, bireylerin ücret değişimlerine verecekleri tepkiye bağlı olarak değişir. Ücretlerde herhangi bir artış olduğu zaman bireyler aynı saat çalışmalarına karşın daha fazla gelir elde edebilecekler ve daha çok mal ve hizmet satın alabileceklerdir. Eğer boş zaman normal bir mal ise yani artan gelir ile birlikte talebi de artıyorsa bu durum aynı zamanda daha fazla boş zaman tercih etmek demektir. Artan ücret ile birlikte daha fazla boş zaman elde etmek ücret artışının gelir etkisinin bir sonucudur. Aynı zamanda ücret artışın potansiyel bir ikame etkisi de söz konusudur. Daha yüksek bir ücret düzeyi boş zamanın da daha pahalı bir mal olduğunu göstermektedir (Case ve Fair, 2006). 
Bireylerin emek arzı konusunda karar verirken çalışmak ve boş zaman geçirmek üzere iki temel aktiviteye odaklandıkları görülüyor. Boş zaman emek arzı dışındaki bütün kavramları kapsamaktadır. İnsanların çoğu için boş zaman çalışmaktan daha eğlencelidir. Bu nedenle kişileri çalışmaya teşvik etmek için iyi bir ücret teklif etmek gereklidir (Parkin, 2012: 422-424). Bireylerin çalıştığı ve boş zaman geçirdiği saateler olarak baktığımızda günü iki bölüme ayırmaktayız. Bireylerin ya da tüketicilerin neden sürekli çalıştıklarını sorduğumuzda; çalışmak demek gelir elde etmek demektir ve bireyler boş zamanlarındaki faaliyetleri için gerekli ödemeleri de bu gelirle yapacaklardır. Boş zaman kavramı basit bir şekilde yemek yemek, uyumak gibi bireylerin çalışmak dişında yaptığı tüm şeyleri kapsamaktadır (Besanko vd., 187-190). Bireyler hiç ya da çok az gelire sahip oldukları zaman yaşamlarını sürdürmek ve sosyal hayatta var olabilmek için çalışmayı tercih edeceklerdir. Bu durumda emek arzı ücretin artan bir fonksiyonu olacak ve emek arz eğrisi klasik olarak pozitif eğimli bir konumda alacaktır. Ancak artan gelir ile birlikte bireylerin boş zaman ve çalışma ile ilgili kararlarında bir takım değişmelerin olması da yüksek bir olasılıktır.

Tüketici nispeten daha yüksek tüketim için daha fazla çalışmayı ya da daha az miktarda tüketim için az çalışmayı tercih edebilir. Tüketici tercihleri ile bütçe kısıtı arasındaki ilişki neticesinde tüketim miktarı ve emek arzı belirlenecektir. Başlangıçta bireylerin çalışıp çalışmadığına bakılmaksızın elde ettiği bir gelirin olduğunu varsayalım. Elde edilen gelir daha önceki yatırımlardan ya da yakınlardan elde edilmiş olabilir. Bu gelir miktarını M ile gösterelim ve buna emek dışı gelir olarak nitelendirelim. Bireylerin emek dışı gelirleri 0 olabilir ancak biz burada pozitif bir gelirin olduğunu varsayıyoruz. Bu durumda elde edilecek bütçe sınır aşağıdaki 1 nolu eşitlikteki gibi olacaktır (Varian, 2014: 173-175).

$$
\mathrm{pC}=\mathrm{M}+\mathrm{wL}
$$

Burada yer alan p- fiyatları, C-tüketim miktarını, w-ücreti ve L-emek arzını göstermektedir. Bu durumda bireylerin tükettikleri mal ve hizmetlerin değerleri emek dışı geliri ile emek geliri toplamına eşit olacaktır. 1 nolu eşitlik ile ilgili düzenleme yaparak emek dışı geliri yalnız bırakıyoruz ve 2 nolu eşitliği elde ediyoruz.

$$
\begin{aligned}
& \mathrm{pC}-\mathrm{wL}=\mathrm{M} \\
& \mathrm{pC}+\mathrm{w}(\overline{\mathrm{L}}-\mathrm{L})=\mathrm{M}+\mathrm{w} \overline{\mathrm{L}} \\
& \overline{\mathrm{C}}=\mathrm{M} / \mathrm{p} \text { eşitliği tüketicinin hiç çalışmaması durumunda yapacağı tüketimi göstermektedir. } \\
& \mathrm{pC}+\mathrm{w}(\overline{\mathrm{L}}-\mathrm{L})=\mathrm{p} \overline{\mathrm{C}}+\mathrm{wL}
\end{aligned}
$$

$\overline{\mathrm{L}}$ - L çalışılmayan zamanı yani dinlenme süresini göstermektedir. $\mathrm{R}=\overline{\mathrm{L}}-\mathrm{L}$ iken toplam boşta geçirilen zaman miktarı $\overline{\mathrm{R}}=\overline{\mathrm{L}}$ olduğu zaman yeni bütçe kısıtı da 4 nolu eşitlikteki halini alır.

$$
p C+w R=p \bar{C}+w \bar{R}
$$

5 nolu eşitliğe baktığımızda 1 nolu eşitlikten farklı bir şey olmadığı görülmektedir. Bu durumda bireylerin ücret gelirinin sadece çalışmaya bağlı olmadığını aynı zamanda boşta geçirilen zamanın da bedeli olduğu görülmektedir (Varian, 2014: 173-175). Yani bireylerin sadece çalışıp gelir elde etmeleri yanı sıra eğlenerek ya da başka bir sosyal aktivite ile harcadıkları zamanın da bir karşılığı vardır. Emek sahibi kimse eğer zamanını boşta geçirmemiş olsaydı, boşta geçen zaman çalışması halinde elde edeceği ücretle kadar bir gelire sahip olacaktı. İşte bu gelir miktarı boş zaman tercih etmenin firsat maliyetini göstermektedir.

$\mathrm{Bu}$ açıklamalar doğrultusunda klasik olarak bilinen ve pozitif eğime sahip olan emek arzı belirli bir noktadan sonra geriye büküm yapmakta ya da tersine dönmektedir sonucuna ulaşılır. Emek sahibi herhangi bir kimse ücret düzeyi $\mathrm{W}_{0}$ iken $\mathrm{L}_{0}$ kadar emek arz etmektedir. Ücret düzeyi $\mathrm{W}_{1}$ 'e yükseldiği zaman işçinin emek arz miktarı $\mathrm{L}_{1}$ 'e çıkmaktadır. Ancak ücretler $\mathrm{W}_{3}$ seviyesine çıktığında bireyin emek arzı $\mathrm{L}_{2}$ 'ye gerilemektedir (Şekil-1). 


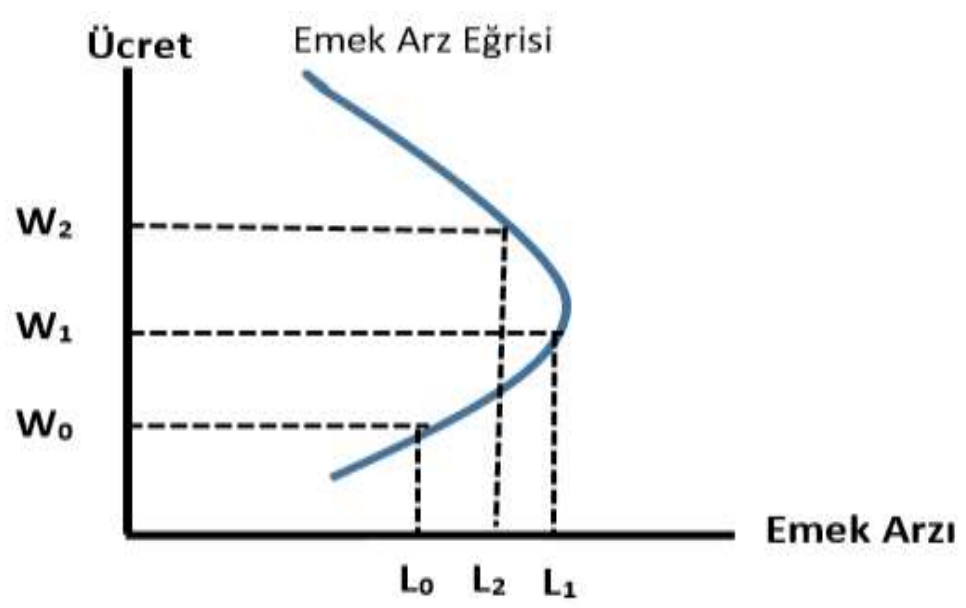

Şekil 1. Tersine Dönen Emek Arz Eğrisi

Bireylerin boş zaman faaliyetlerinden zevk aldıkları da bir gerçektir. Bir gün sadece yirmi dört saatten oluştuğu için bireylerin boş zaman tercihleri aslında aynı zamanda emek arzı içinde bir tercihin göstergesidir. Ücretlerde meydana gelen bir artış herhangi bir mal veya hizmetin satın alınması için gerekli olan çalışma süresini de azaltacaktır. Bu durumda ortaya ikame ve gelir etkisi çıkmaktadır (Besanko vd., 187-190). Çalışmak yani daha fazla emek arz etmek ile emek arzını azaltmak arasında yapılacak bir tercihin birçok nedeni olabilir. Başlangıçta bireylerin artan ücret karşısında çalışmayı tercih etmeleri ikame etkisinden kaynaklanmaktadır. Bu durumda bireyler boş zamana karşı çalışmayı ikame etmektedirler. İşü̈ü sahiplerinin daha fazla emek arz ettikleri bu durumda ikame etkisi gelir etkisinde daha büyüktür.

Diğer bir noktada ise bireylerin artan gelir ile birlikte refah düzeylerinde de bir iyileşme olması belirleyici bir faktör olmaktadır. Artan refah düzeyi dışında kişilerin kendilerine ve ailesine daha fazla zaman ayırmak istemeleri de emek arzı için önemli bir belirleyicidir. Bunlar dışında bireyler sosyal yaşamdaki eğlence, spor, eğitim, kurs gibi birçok faaliyete katılmak ya da daha fazla yer almak için de emek arzını değiştirebilir. Bu durumda emek sahipleri daha az emek arzında bulunacaklar ve boş zamanı tercih edeceklerdir. Bu defa bireylerin saydığımız faktörlerin de etkisiyle çalışma yerine boş zamanı tercih etmeleri gelir etkisinin ikame etkisinden daha büyük olmasından kaynaklanmaktadır.

\section{Yöntem ve Bulgular}

Bilinen regresyon analizinde bağımlı bir değişkenin tek ya da daha fazla bağımsız değişkenlerle olan ilişkisi incelenmektedir. Daha önceden bilinen ya da sabit olan değerler ile bağımlı değişken için hesaplamalar yapılır (Gujarati, 2004). Bu sözünü ettiğimiz durum doğrusal regresyon modelleri için geçerlidir ancak tasarlanan modelde kategorik değişkenlerin var olması bir takım varsayımların da aksaması anlamına gelmektedir. Eğer kurulacak modelde kategorik değişkenler yer alıyorsa, bağımsız değişkenlerin dağılımı konusunda varsayımda bulunmayan lojistik regresyonun tercihi daha doğru olacaktır (Sharma, 1996).

Aslında temel olarak tüm regresyon modelleri doğrusal değildir. Dolayısıyla regresyon modelleri için doğrusal olan ve doğrusal olmayan modeller olarak bir ayrım yapmamız söz konusudur. Kurulan regresyon modellerinin bir kısmı doğrusal görünmese dahi kendiliğinden doğrusal olma olasıllı̆̆ taşımaktadır. Kendiliğinden doğrusal olma ihtimali taşıyan bu modeller eğer uygun dönüşüm yöntemleri seçilirse doğrusal bir yapıya sahip olacaklardır. Bu modeller genellikle probit ve logit (lojistik) regresyon modelleri olup, temelde neredeyse aynı olan bu modellerin tek fark fonksiyon denklemlerindedir (Gujarati, 2004).

$P i=E(Y=1 \mid X i)=\beta 1+\beta 2 X i$

$P i=E(Y=1 \mid X i)=\frac{1}{1+\mathrm{e}-(\beta 1+\beta 2 \mathrm{Xi})}$

$P i=\frac{1}{1+e-Z^{i}}=\frac{e^{z}}{1+e^{z}}$

8 numaralı denklem kümülatif lojistik dağılım fonksiyonunu gösterir. Modelde yer alan ; zi $-\infty$ ile $+\infty$ arasında ve pi ise 0 ile 1arasında değerler alır (Gujarati, 2004).

Kurulan lojistik modelde yer alan bağımsız değişken sayısı regresyon modelinin de isimlendirilmesinde etkilidir. Eğer tek bir bağımsız değişken varsa tek değişkenli lojistik regresyon var demektir. Doğrusal regresyona benzer şekilde bağımsız değişkenlerin sayısı birden fazla ise çok değişkenli lojistik analizden söz edilecektir. Lojistik modeller bağımlı 
değişkenin aldığıdığı değere göre de farklı şekillerde tanımlanmaktadır. Bağımlı değişken; iki farklı değer almışsa ikili lojistik model, ikiden fazla değer almışsa multinominal lojistik, sıralı değerler almışsa sıralı lojistik model söz konusu olacaktır (Stephenson, 2008). İki farklı değer alan regresyon modeli olan lojistik regresyon, herhangi bir olayın gerçekleşme olasılığını her bir değişkenin ne şekilde etkilediğinin saptanmasına sağlamaktadır (Freese ve Long, 2006).

Tablo 1.Modelde Yer Alan Değişken Açıklamaları

\begin{tabular}{|c|c|c|}
\hline Türü & Kodu & Açıklaması \\
\hline Bă̆ımlı Değişken & boș_zaman & Yeterli zamana sahip ise 1 değilse 0 değerini alır. \\
\hline \multirow{9}{*}{ Bağımsız Değişkenler } & yas & $15-99$ arası değer alır. \\
\hline & medeni_durum & Evli ise 1 değilse 0 değerini alır. \\
\hline & egitim & Lise ve üstü ise 1 , ortaokul ve altı ise 0 değrini alır. \\
\hline & otomobil & Otomobil sahibi ise 1 değilse 0 değerini alır. \\
\hline & yasanilan_yer & Kentte yaşoyor ise 1 , kırsal alanda yaşıyorsa 0 değerini alır \\
\hline & aylik_gelir & Aylık hane geliri asgari ücretten fazla ise 1 değilse 0 değerini alır. \\
\hline & fert_iş_durum & fert bir işte çalışıyorsa 1 çalışmıyorsa 0 \\
\hline & saglik_durum & Herhangi bir sağlık sorunu yoksa 1 varsa 0 değerini alır. \\
\hline & cinsyet & Erkek ise 1 kadın ise 0 değerini alır. \\
\hline
\end{tabular}

TÜİK'ten temin edilen hanehalkı araştırması anketinden elde edilen veriler kullanılarak, Türkiye için gelir ve boş zaman tercihi arasındaki ilişki incelenmiştir. Tersine dönen emek arz eğrisinin Türkiye'de geçerli olup olmadığının analizi için kurulan modelde yer alan bağımlı ve bağımsız değişkenler ile bilgiler tablo 1'de yer almaktadır. Analiz için kullandığımız model lojistik yapıda kurulduğu olduğu için yaş değişkeni dışındaki açıklanan ve açıklayıcı tüm değişkenlere ikili değerler verilmiştir. Bağımlı değişken olarak yeterli boş zamana sahip olmak veya sahip olamamak seçilmiştir. Bağımsız değişkenler ise; yaş, medeni durum, eğitim seviyesi, yaşanılan yer, otomobil sahibi olmak, işteki durum, sağlık durumu, cinsiyet, yaşanılan yer ve hanenin aylık ortalama ücret geliri seçilmiştir.

Bireylerin yeterli boş zamana sahip olması 1, yeterli boş zamana sahip olamaması ise 0 değerini almaktadır. Modelde yer alan tüm bağımsız değişkenlerin de gerçekleşme olasılığ 1 olarak kodlanırken gerçekleşmeme olasılı̆̆ da 0 olarak kodlanmıştır. Örneğin medeni durum değişkeni evli ise 1 evli değilse 0 , eğitim seviyesi lise ve üstünde ise 1 eğer daha düşük ise 0 değerini almıştır.

Tablo 2. Özet Bilgiler

\begin{tabular}{lll}
\hline \hline Yaş & Ortalama (15 ve üzeri) (\%) & 33 \\
Medeni Durum & Evli (\%) & 57 \\
& Evli Değil (\%) & 43 \\
Eğitim Durumu & Lise ve Üstü (\%) & 47 \\
Cinsiyet & Ortaokul ve Altı (\%) & 53 \\
& Kadın (\%) & 52 \\
Otomobil & Erkek (\%) & 48 \\
& Var (\%) & 35 \\
Yaşanılan Yer & Yok (\%) & 65 \\
& Kent (\%) & 57 \\
Hane ortalama ücret geliri & Kir (\%) & 43 \\
& Asgari Ücretten Fazla (\%) & 58 \\
\hline \hline
\end{tabular}

Kullanılan örneklemde yer alan bireylerin \%57'si evli ve \%52'si kadınlardan oluşmaktadır. Eğitim seviyesi lise ve üstü olan bireylerin oranı ise $\% 47$ 'dir. Ortalama hane gelirinin asgari ücretten daha fazla olduğu hane oranı \%58 ve kentlerde yaşayan bireylerin oranı da $\% 57$ 'dir (tablo 2). 
Tablo 3. Model Tahmin Sonuçları

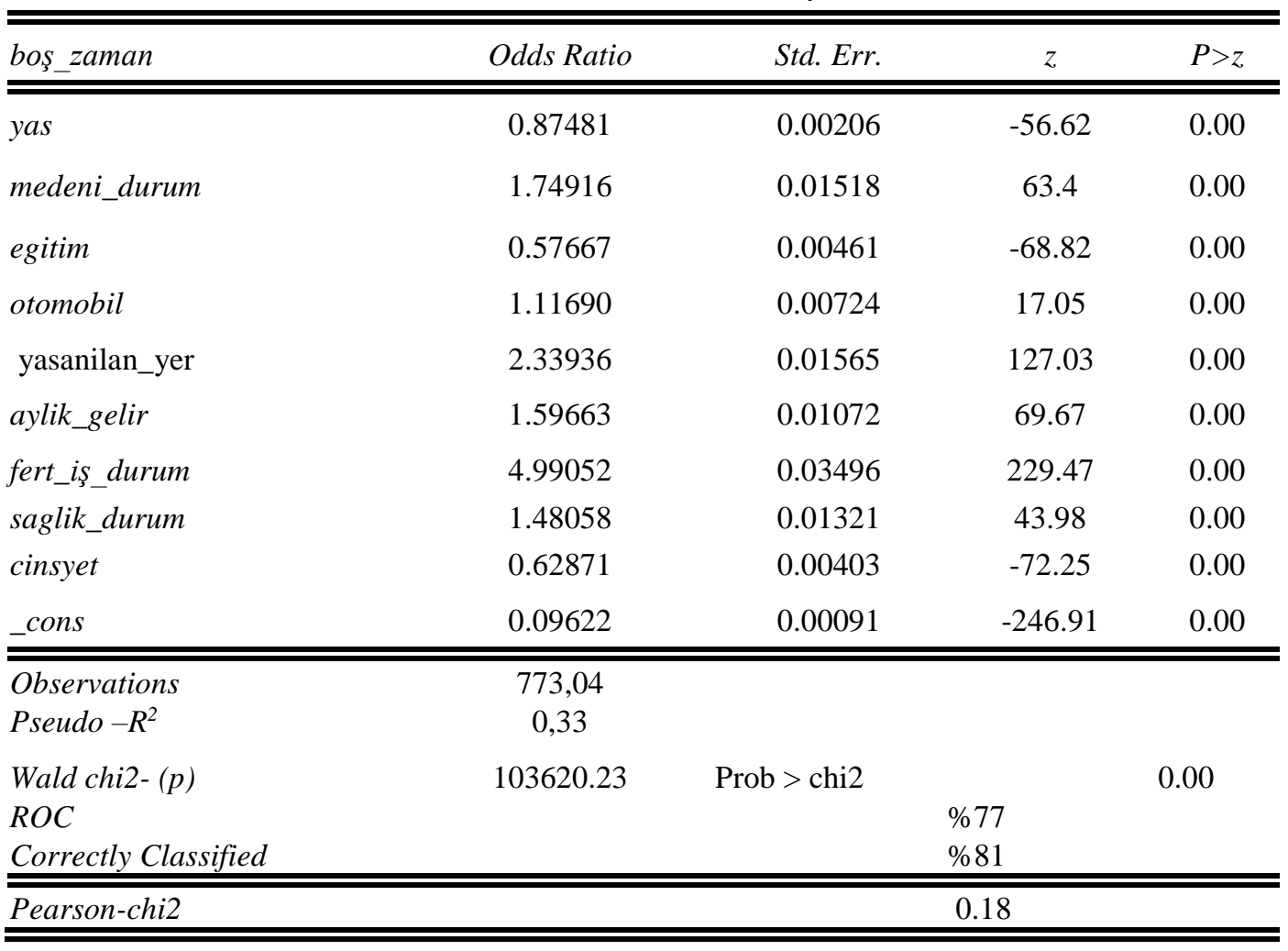

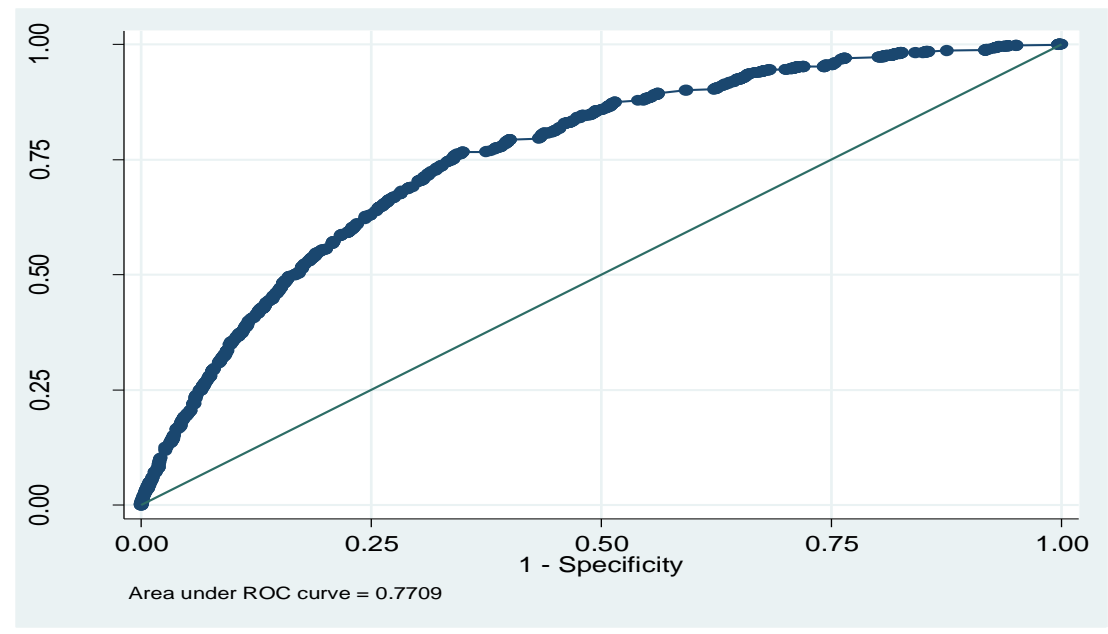

Grafik1. ROC (Receiver Operating Characteristic) Analiz Sonucu

Türkiye'de tersine dönen emek arz eğrisinin analizi için kurduğumuz lojistik modelin sonuçları tablo 3'te yer almaktadır. Kurulan modelin PseudoR ${ }^{2}$ değerinin 0.32 olduğu görülmektedir. Lojistik modelin genel anlamlılığının sınaması Wald-chi2 (Ki-Kare) olasılık değeri ile yapılmaktadır. Tablo 3'e baktığımız zaman Wald-chi2 olasılık değerinin $\% 5$ düzeyinde anlamlı olduğu yani modelin bir bütün olarak anlamlı olduğu görülmektedir.

Lojistik regresyon modellerinin açıklama gücünü belirlemek için ROC (Receiver Operating Characteristic) analizi ve sınıflandırma tablosundan yararlanılmaktadır. Modelimizin ROC değeri \%77 ve doğru sınıflandırma oranı da \%81 düzeyindedir. Modelde yer alan veriler ile modelin uyumlu olup olmadıklarını ise Pearson-chi2 değerinden görebiliriz. Pearson-chi2 olasıllk değeri 0.18 olarak tespit edilmiş olup veriler model ile uyumludur.

Modelde kullanılan tüm bağımsız değişken \%1 düzeyinde istatistiki olarak anlamlıdır. Eğitim düzeyinin, yaşın ve cinsiyetin boş zaman üzerindeki etkisinin istatistiki olarak anlamlı ancak negatif olduğu görülmektedir. Bireylerin yaş artışı ile birlikte istedikleri faaliyetlere zaman ayırabilmeleri (boş zamana sahip olma) olasılığını 0.62 kat azalmaktadır. Eğitim seviyesinin lise ve üstü olmasının ortaokul ve altı bir seviyede olmaya göre bireylerin istedikleri faaliyetlere zaman ayırabilmeleri olasılığını 0.57 kat azalttığı tespit edilmiştir. 
Medeni duruma baktığımız zaman evli olmanın bekar olmaya göre istedikleri faaliyetlere zaman ayırabilmeleri (boş zamana tercihi) olasılığını 1.75 kat artırdığı, benzer şekilde herhangi bir işte çalışmanın bir işte çalışmamaya göre boş zamana sahip olma olasılığını 5 kat artıdğını saptanmıştır. Kişilerin herhangi bir sağlık probleminin olmamasının sağlık problemlerinin olmasına göre istenilen aktivitelere zaman ayırma olasılığını 1.5 kat artırmaktadır. Bireylerin kentte yaşıyor olmaları kırsal alanda yaşamaya göre boş zaman sahibi olma olasılığını 2.3 kat yükselmektedir. Bunlar dışında hanehalkı ortalama aylık gelirinin asgari ücretten daha fazla olmasının boş zamana sahip olma olasalığını 1.6 kat artırdığı görülmektedir. Bu durumda bireyler artan gelir ile birlikte daha fazla boş zamana sahip olmaktadırlar. Burada artan gelir sonucu ortaya çıkan gelir etkisi çalışma yönünde oluşacak ikame etkisine baskındır. Dolayısılya bireylerin emek arz eğrisi genel varsayımın aksine artan gelir karşısında geriye bükümlü bir hal almaktadır.

\section{Sonuç ve Tartışma}

Rasyonel bir insanın tüketici olarak temel amacı faydasını maksimum yapmaktadır. Bunun içinde elde edeceği gelirin en yüksek olması ya da mal ve hizmet ödemelerinin mümkünse minimum olması gerekir. Ekonomide her iki durumun da aynı anda geçekleşmesi pek mümkün değildir. Mal ve hizmet fiyatları tüketicilerin müdahalesi dışında kaldığı için bireyler gelirlerini maksimum düzeye çıkarmak için çaba harcayacaklardır. Bu çaba üretim sürecine kişisel olarak dahil olmakla başlayacak ve emek arzının oluşumunun temelini oluşturacaktır. Kişilerin emekleri ile üretime katılmaları en önemli üretim faktörünün de üretim fonksiyonuna eklenmesi demektedir. Üretime katılan emek sahipleri üretim sonucu meydana getirilen hasıladan/gelirden paylarını ücret olarak alacaklardır. Emek arzını beliryelen doğrudan emek sahipleri olduğuna göre ücret artışı karşısında bireyler daha fazla çalışmak isteyeceklerdir. Daha fazla çalışmanın neticesinde de daha çok ücret geliri elde edeceklerdir. Buraya kadar gerçekleşen faaliyetler klasik olarak emek arzının ücretin artan bir fonksiyonu olmasının bir sonucudur. Ancak zaman içerisinde emek arzı ücretin artan bir fonksiyonu olmaktan azalan bir fonksiyonu olmaya doğru hareket etmektedir. Bu durumda emek sahiplerinin çalışmak ya da boş zaman olmak üzere iki yönlü bir tercihi söz konusu olacaktır. İkili seçenekli bir tercihin ortaya çıkması ile boş zaman ve çalışmak birbirinin ikamesi olan iki farklı mal halini almaktadır.

Gelir etkisi ile boş zaman tercihinin de artmış olması insanların sosyal yaşamın farklı alanlarında da daha fazla yer alacağı anlamına gelmektedir. Aslında bu durum bireylerin alternatif (fırsat) maliyet yüklenmelerinin bir sonucudur. İnsanlar bir şeyi yapmak yada yapmamak için karar aldıkları zaman bu durum daima bir alternatif maliyeti bulunmaktadır. Bireyler eğer boşta zaman geçirmek isterlerse; çalışılmayan zaman kadar çalışılsaydı elde edilecek gelir kadar da parasal bir maliyetin söz konusu olduğu görülecektir. Bireyler elde edecekleri bu fazladan gelir ile satın alabilecekleri mal ve hizmetlerden de yoksun kalacaklardır. Bu durumda insanların daha fazla boş zaman sahip olmaları ancak belirli bir gelir düzeyine ve buna bağlı olarak nispeten yüksek refah seviyesine ulaşmaları sonrasında gerçekleşmektedir. Bu durumda bireyler için pozitif gelir etkisi negatif ikame etkisine göre tercih edilebilir bir noktadadır.

Literatürde gelir artışı ile birlikte bireylerin emek arzının şeklinin nasıl olacağına yönelik az da olsa çalışmalar bulunmaktadır. Bu konuda Türkiye özelinde henüz hiçbir çalışmanın yapılmamış olmasını makalemizin literatüre en önemlisi katkısıdır. Elde ettiğimiz bulguların ayrıntılarına baktığımızda tersine dönen emek arzının Türkiye'deki hanehalkı için de geçerli olduğu saptanmıştır. Türkiye'de bireyler artan gelir sonucunda pozitif gelir etkisi ile boş zamana daha fazla yönelmektedirler. Lojistik regresyon analizi sonucunda ortaya çıkan bu sonuç literatürde yapılan çalışmalar ile de uyumludur. Elde ettiğimiz diğer önemli bulgular ise; yaşın, eğitim düzeyinin ve cinsiyetin boş zaman tercihi üzerinde negatif bir etkiye sahip olmalarıdır. Artan eğitim seviyesi ile iş yaşamına girişin gecikmesi ya da bireylerin yüksek eğitim düzeyi ile birlikte işteki pozisyonu daha yüksek olması bu negatif etkinin sebepleri olarak sıralanabilir. Cinsiyetin erkek olmasının boş zaman tercihini azaltmasının nedeni ise Türkiye'de kadınların işgücüne katılım oranlarının zaman içinde artmasına rağmen hala erkeklerin yarısı olması olarak açıklanabilir. Zaten işgücüne düşük oranlarda ve zamanlama olarak daha geç dahil olan kadınların erkeklere göre daha fazla üretim sürecinde kalmak istemeleri de doğal bir sonuçtur.

Analizde elde edilen diğer bir sonuç da şehirlerde yaşayan bireylerin asgari ücretten daha az gelire sahip olma oranı $\% 35$ iken, bu oran kırsal bölgelerde \%55'e yükselmektedir. Şehirlerde yaşamanın etkisi doğrudan gelire yansımakta ve elde edilen ücret geliri de artmaktadır. Artan ücret gelirinin de etkisiyle şehirlerde yaşıyor olmak tersine dönen emek arz eğrisini destekleyici şekilde boş zaman tercihi 2.5 kat artırmaktadır. Modelimizin ortaya koyduğu ve literatürdeki çalışmalarla örtüşen diğer bir sonuç ise evli olmanın bir takım sosyal faaliyetler için yeterli boş zaman sahip olma olasılığını artırmasıdır. Aslında bu sonuç evli olmanın ortalama hane gelirini artırması ile ilgili bir durumdur. Şehirde yaşamaya benzer şekilde gelir artışının pozitif etkisi ikame etkisine göre daha baskın olmuştur. 


\section{KAYNAKÇA}

Besanko, D. A. ve Braeutigam, R. R. (2010). Microeconomics. 4th. ed. John Wiley \& Sons.

Case, K. E. ve Fair, R. C. (2006). Principles of Microeconomics. Pearson Education Company.

Dessing, M. (2002). "Labor Supply, The family and Poverty: the S-shaped Labor Supply Curve". Journal of Economic Behavior \& Organization, 49(4), 433-458.

Dimova, R., Michaelowa, K., ve Weber, A. (2004). "Ganyu Labor in Malawi: Efficiency Problems and Determinants of Supply. Brunel University.

Ellis, G. (1981). "The Backward-Bending Supply Curve of Labor in Africa: Models, Evidence, and Interpretation: And Why It Makes a Difference". The Journal of Developing Areas, 15(2), 251-274.

Frey, G. E., Chamberlain, J. L. ve Prestemon, J. P. (2018). "The Potential for A Backward-Bending Supply Curve of NonTimber Forest Products: An Empirical Case Study of Wild American Ginseng Production. Forest Policy and Economics, 97, 97-109.

Gujarati, D. N. (2004). Basic Econometrics. The Mc-Graw Hill.

Just, R. E. Ve Zilberman, D. (1992). "In Defense of Fence to Fence: Can the Backward Bending Supply Curve Exist?". Journal of Agricultural and Resource Economics, 277-285.

Krugman, P. ve Wells, R. (2010). Microeconomics.New York: Worth Pub-lishers.

Licona, G. (2000). "Reshaping the Labor Supply Curve for the Poor in Río De Janeiro". Brasil: Annual Meeting of the Latin American And Caribbean Economic Association.

Lin, C. C. (2003). "A backward- bending Labor Supply Curve Without an Income Effect". Oxford Economic Papers, 55(2), 336-343.

Long, S. J. ve Freese, J. (2006). Regression Models for Categorical Dependent Variables Using Stata. Stata Press.

Mankiw, G. (2012). Principles of Microeconomics. 6th edn Mason. OH: SouthWestern Cengage Learning.

Miracle, M. P. Ve Fetter, B. (1970). "Backward-sloping Labor-supply Functions and African Economic Behavior". Economic Development and Cultural Change, 18(2), 240-251.

Nakamura, A. ve Nakamura, M. (1981). "A Comparison of the Labor Force Behavior of Married Women in the United States and Canada, with Special Attention to the Impact of Income Taxes". Econometrica: Journal of the Econometric Society, 451-489.

Palley, T. I. (2003). "The Backward-Bending Phillips Curve and The Minimum Unemployment Rate of Inflation: Wage Adjustment with Opportunistic Firms". The Manchester School, 71(1), 35-50.

Parkin, M., Bade, R., Parkin, M., King, H. B. ve Cohen, A. J. (2000). Microeconomics: Canada in the Global Gnvironment. Addison Wesley Longman.

Pham, T. T. ve Flaaten, O. (2013). "The Backward-Bending Supply Curve in Fisheries-Revisited". Journal of Sustainable Development; 6(6), 15-33.

Plott, C. R. (2000). "Market Stability: Backward- Bending Supply in a Laboratory Experimental Market". 1999 Presidential Address. Western Economic Association. Economic Inquiry, 38(1), 1-18.

Rahman, A. J. (2013). "An Econometric Analysis of the "Backward-Bending" Labour Supply of Canadian Women”. Undergraduate Economic Review, 10(1), 6.

Rasmussen, B. S. (1998). "Long Run Effects of Employment and Payroll Taxes in an Efficiency Wage Model". Economics Letters, 58(2), 245-253.

Robinson, C. ve Tomes, N. (1985). "More on the Labour Supply of Canadian Women". Canadian Journal of Economics, 156-163.

Sharma, S. (1996). Applied Multivariate Techniques, John Wily \& Sons Inc., Canada.

Stephenson, B., Cook, D., Dixon, P., Duckworth, W., Kaiser, M., Koehler, K., ve Meeker, W. (2008)http://modul.repo.mercubuanayogya.ac.id/modul/files/openjournal/Journal\%200f\%20Engineering/GLM logistic.Rpackage.pdf. 02.09.2019

Stucky, K. A. "The Backward-Bending Supply Curve of Gender Specific Work Ethics In Emerging Third World Countries." $\quad$ http://citeseerx.ist.psu.edu/viewdoc/download?doi=10.1.1.196.8764\&rep=rep1\&type=pdf 11.09.2019

Tellez, M., Spetz, J., Seago, J. A., Harrington, C. M.ve Kitchener, M. (2009). "Do Wages Matter?: A Backward Bend in the 2004 California RN Labor Supply”. Policy, Politics, \& Nursing Practice, 10(3), 195-203.

Varian, H. R. (2014). Intermediate Microeconomics with Calculus: A Modern Approach. WW Norton \& Company. 